\title{
Selectivity of HeRbicides Inhibitors of Photosystem II FoR Sugarcane Cultivars ${ }^{1}$
}

\author{
Seletividade de Herbicidas Inibidores do Fotossistema II para Cultivares de Cana-de-Açúcar
}

SIMÕES, P.S. ${ }^{2}$, CARBONARI, C.A. ${ }^{2}$, NASCENTES, R.F. ${ }^{2}$, STASIEVSKI, A. ${ }^{2}$, and VELINI, E.D. ${ }^{2}$

\begin{abstract}
For the successful execution of chemical weed control in sugarcane crop, the selectivity of herbicides is a factor of great importance to maximize crop yield. Each cultivar may respond differently to the same herbicide in the same dose, and selectivity is not only determined by the visual presence or absence of phytotoxicity. Thus, the aim of this study was to evaluate the effects of herbicides amicarbazone, tebuthiuron, and diuron + hexazinona on the electron transport rate in photosystem II (ETR), along with the development and yield of sugarcane cultivars RB867515, CTC 4, CTC 9, and CTC 17 in greenhouse, and field conditions. Under greenhouse conditions ETR was assessed by a portable fluorometer, aa well as dry weight and phytotoxicity of the plants. In field evaluations, ETR, number of stems, yield and technological characteristics were assessed. In the greenhouse, the tebuthiuron herbicide caused the lowest reduction levels of ETR, phytotoxicity and dry weight of different sugarcane cultivars, followed by amicarbazone, and diuron + hexazinona. The effects of herbicides in ETR and phytotoxicity were more intense in greenhouse conditions than in field conditions for all cultivars. Herbicides tebuthiuron, amicarbazone and diuron + hexazinoa were selective for all evaluated cultivars, and reductions in the ETR after herbicide application did not affect the yield and technological characteristics of sugarcane cultivars.
\end{abstract}

Keywords: amicarbazone, tebuthiuron, diuron, hexazinona, electron transport rate, Saccharum spp.

RESUMO - Para o sucesso na execução do controle quimico de plantas daninhas na cultura da canade-açúcar, a seletividade dos herbicidas é um fator determinante e de grande importância para maximizar a produtividade da cultura. Cada cultivar pode responder de maneira diferente ao mesmo herbicida na mesma dose, e a seletividade não é somente determinada por presença ou não da fitotoxicidade visual. Assim, objetivou-se neste trabalho avaliar os efeitos dos herbicidas amicarbazone, tebuthiuron e diuron + hexazinona sobre a taxa de transporte de elétrons no fotossistema II (ETR), desenvolvimento e produtividade dos cultivares RB867515, CTC 4, CTC 9 e CTC 17 em casa de vegetação e em campo. Em casa de vegetação foram realizadas avaliações da ETR, por meio de um fluorômetro portátil, massa de matéria seca e fitotoxicidade das plantas; em campo, foram feitas avaliações de ETR, número de colmos, produtividade e análises tecnológicas. Em condições controladas, o herbicida tebuthiuron causou os menores niveis de redução da ETR, fitotoxicidade e massa de matéria seca dos diferentes cultivares de cana-de-açúcar, seguido por amicarbazone e diuron thexazinona. Os efeitos dos herbicidas na ETR e fitotoxicidade foram muito mais intensos em casa de vegetação do que em campo para os diferentes cultivares. Os herbicidas tebuthiuron, amicarbazone e diuron thexazinona foram seletivos para os diferentes cultivares, e as reduções de ETR após a aplicação dos herbicidas não influenciaram a produtividade e as características tecnológicas da cana-de-açúcar.

Palavras-chave: amicarbazone, tebuthiuron, diuron, hexazinona, taxa de transporte de elétron, Saccharum spp.

Recebido para publicação em 25.2.2016 e aprovado em 3.5.2016.

Universidade Estadual Paulista "Júlio de Mesquita Filho" (UNESP), Botucatu-SP, Brasil, <pliniosaulosimoes@hotmail.com>.

Planta Daninha, Viçosa-MG, v. 34, n. 4, p. 803-814, 2016 


\section{INTRODUCTION}

The culture of sugarcane is one of the most important in the history of Brazil, it is the raw material for the production of several products, including alcohol and sugar. Currently, this culture is also relevant for the generation of energy derived from the incineration of trash and milling waste. Brazil is currently the largest producer and exporter of products derived from sugarcane, with an acreage of about 9 million hectares and the grinding of 665 million tons of sugarcane annually (Conab, 2016), mainly from the state of São Paulo.

Sugarcane production faces challenges associated with several factors, among them, weed interference, which could represent significant losses in production, as well as reduced quality of raw materials and longevity of sugarcane fields, difficulty of harvesting, and the hosting of pests and diseases (Negrisoli et al., 2004).

Thus, weed management needs to be conducted at the appropriate time and using appropriate methods, in order to reduce losses without causing any damage to the crop. Chemical control is the most widely used management method in most producing areas of sugarcane, because it provides a good cost benefit ratio when compared to other weed control methods.

Despite all the benefits provided by herbicides in weed management, they should be carefully selected, since they can affect in many ways the culture of sugarcane during its development. Their adverse effects are the result of several factors related to the selected herbicide, the environment, the application mode, and the genetic characteristics of each cultivar. Thus, the development and the ongoing employment of new sugarcane cultivars make herbicidal selectivity research permanent for this culture, since it is an essential tool to minimize the risk of reduced productivity.

Selecting the appropriate herbicide means finding one that is able to cause death or growth inhibition of a particular plant without causing economic damage to the crop (Anderson, 1993; Oliveira Jr. and
Constantin, 2001). Herbicide selectivity may not be determined solely by detecting visual symptoms of phytotoxicity, since there are cases where a herbicide can reduce crop yield without causing any visible manifestation of symptoms (Negrisoli et al., 2004).

In Brazil, most of the chemical groups of herbicides registered for the cultivation of sugarcane inhibit the flow of electrons in PSII (photosystem II). Some examples have been herbicides belonging to the group triazinones (hexazinone and metribuzin), of triazolinones (amicarbazone) and ureas (diuron and tebuthiuron) (Rodrigues and Almeida, 2011). According to Franconere (2010), in production fields of sugarcane in 2009 , about $46 \%$ of the areas were treated with herbicides that acted on the inhibition of photosystem II (PSII).

Considering that the different cultivars studied may have different tolerance to herbicide application, this study aimed to assess the selectivity of herbicides that act as inhibitors of photosystem II (amicarbazone, tebuthiuron and diuron + hexazinone) applied in early post-emergence for different cultivars of sugarcane (RB867515, CTC 4, CTC 9, and CTC 17) in the greenhouse and in the field.

\section{MATERIAL AND METHODS}

\section{Greenhouse experiments}

The experiments were conducted in a greenhouse (average temperature of $28 \pm 3{ }^{\circ} \mathrm{C}$, relative humidity of $65 \pm 5 \%$ without additional lighting). Four varieties of sugarcane were used to conduct the study, namely, RB867515, CTC 4, CTC 9, and CTC 17, using a completely randomized design in a $3 \times 4$ factorial with five replications. The study included three herbicides with different active ingredients and four doses (0 "control", 50, 100 and 200\% of the recommended dose, according to the orientation included in the commercial products). Herbicides and doses used were amicarbazone (Dinamic) 630; 1,260 and 2,520 g a.i. ha-1 (900, 1,800 and 3,600 g p.c. ha-1); tebuthiuron (Lava 800) 520, 1,040 and 2,080 g a.i. ha ${ }^{-1}(650,1,300$ and 2,600 g pc ha-1); and diuron + hexazinone (Velpar-K) $585+165$, $1,170+330$ and $2,340+660$ g a.i. ha ${ }^{-1}(1,250$, 2,500 and $5,000 \mathrm{~g} \mathrm{pc} \mathrm{ha}^{-11}$. 
To conduct the experiment we used pots filled with 5 liters of clayey soil with $24 \%$ sand, $19 \%$ silt, and $56 \%$ clay with $\mathrm{pH} 4.9$ and $34 \mathrm{~g} \mathrm{dm}^{-3}$ of organic matter. Planting included fertilization according to the needs of the culture of sugarcane, to the Bulletin 100 (Raij et al., 1997), and two toleres containing a gem each were planted.

Herbicide application was made in early post-emergence of sugarcane, when the plants were averaging 40 to $50 \mathrm{~cm}$ tall. In the application of treatments, we used a nozzle installed in a laboratory. The spray bar was composed of four flat fan tips, model XR $11002 \mathrm{VS}$, spaced $0.5 \mathrm{~m}$ with application rate of $200 \mathrm{~L} \mathrm{ha}^{-1}$. The application took place with an average relative humidity of $60 \%$ and average temperature of $32{ }^{\circ} \mathrm{C}$. After the treatments, the pots were kept in the greenhouse.

The electron transport rate at the photosystem II (ETR) was assessed at 1, 2, $3,4,5,6,7,9,13,15,17,21,24,27,30$ and 39 days after application (DAA) of treatments, with a portable fluorometer (Multi-ModeChlorophyllFluorometer OS5p, Opti-Science/Hudson, NY, USA). The measurement of ETR was made in the middle part of the TVD leaf (Top VisibleDewlap) of sugarcane plants, with two readings per pot, at times ranging from 10 to 14 hours. For determining the ETR, we used the Yield protocol.

The visual assessment of phytotoxicity was made 35 days after application (DAA), as percentages notes, where 0 corresponds to no phytotoxicity caused by the herbicide in the plant and 100 plant death as SBCPD (1995).

At 39 DAA, the aerial parts of the plants were collected and dried in an oven with forced air at $60{ }^{\circ} \mathrm{C}$ to constant weight, to later weigh and obtain their dry mass.

\section{Field experiments}

Four experiments were installed in four-cut sugarcane ratoon area, spaced $1.5 \mathrm{~m}$ between rows. Each of the experiments corresponded to one of the following varieties: RB867515, CTC 4, CTC 9 and CTC17.

Physical and (Embrapa, 1997) chemical (Raij et al., 2001) characteristics of soil on the experimental areas are depicted in Table 1, where simple ten samples were made for each compound in the depth of 0 to $0.2 \mathrm{~m}$. After cutting, fertilization was made according to the needs of the culture of sugarcane (Raij et al., 1997). Weather conditions during the conduct of experiments (October 2013 to October 2014) are described in Figure 1.

The experimental design was randomized blocks with six replications, each parcel represented by five lines, three of them of sugarcane $7.5 \mathrm{~m}$ long and $1.5 \mathrm{~m}$ spacing, resulting in installments with an area of $11.25 \mathrm{~m}^{2}$, in all experiments, disregarding one meter from the beginning and end of each plot.

In all experiments, the treatments were amicarbazone (Dinamic) 1,260 g a.i. ha ${ }^{-1}$

Table 1 - Results of chemical and physical analysis of the soil ( 0 to $0.20 \mathrm{~m}$ deep) in the experimental areas in the field

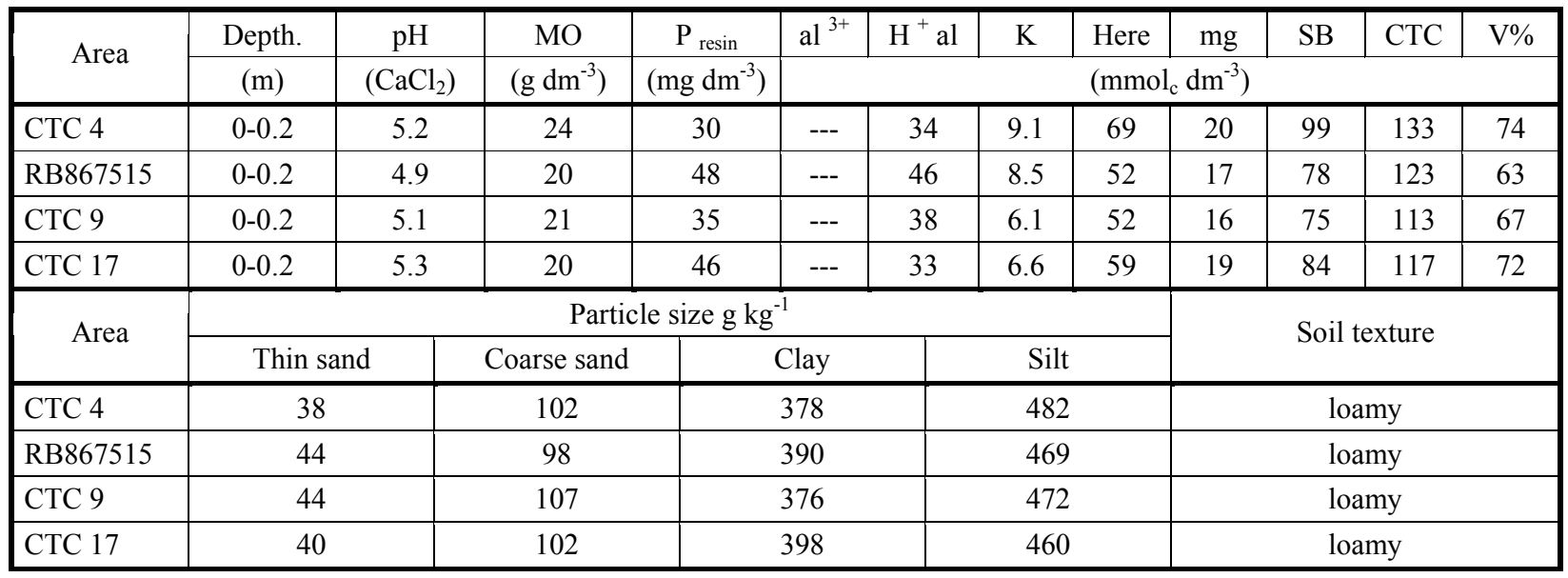




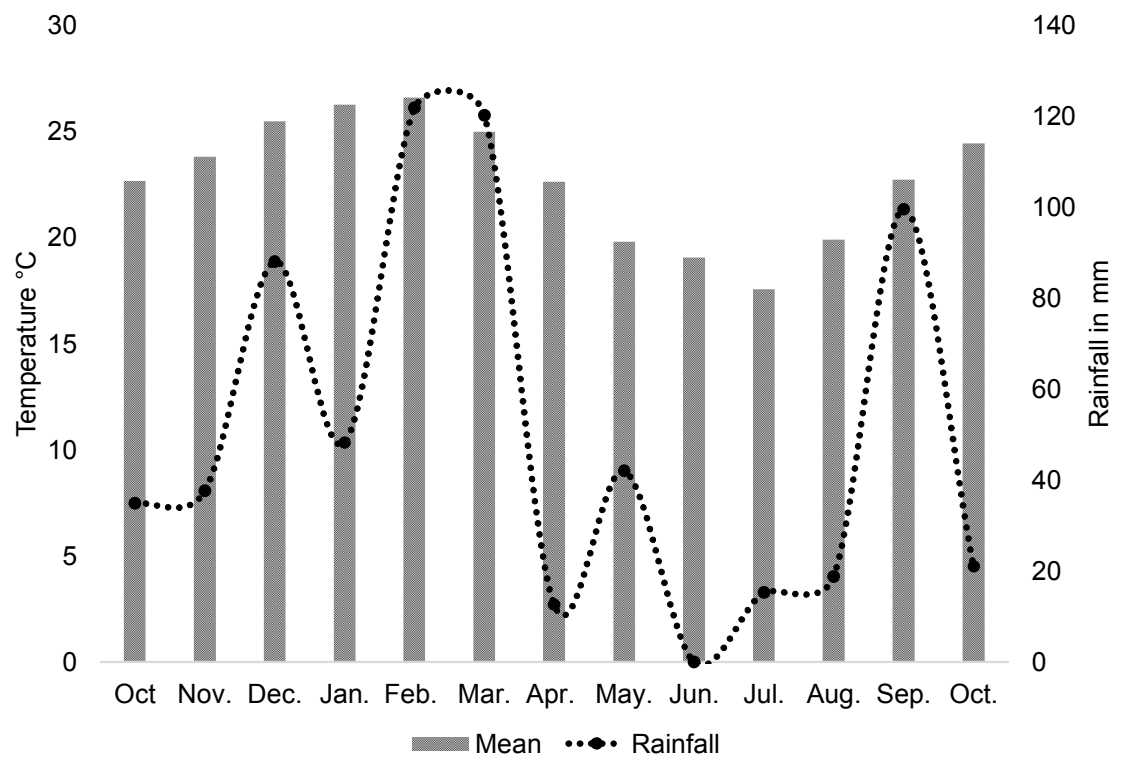

Figure 1 - Rainfall $(\mathrm{mm})$ and average temperature $\left({ }^{\circ} \mathrm{C}\right)$ for the evaluation of the experiments.

(1.800 $\left.\mathrm{g} \mathrm{pc} \mathrm{ha}^{-1}\right)$, tebuthiuron (Lava 800) $1,040 \mathrm{~g}$ a.i. ha- $\mathrm{ha}^{-1}\left(1.300 \mathrm{~g} \mathrm{pc} \mathrm{ha}^{-1}\right)$ and diuron + hexazinone (Velpar-K) 1,170 + 330 g a.i. ha ${ }^{-1}$ $\left(2,500 \mathrm{~g} \mathrm{pc} \mathrm{ha}^{-1}\right)$, applied in early postemergence of the crop when the plants were height of 25 to $30 \mathrm{~cm}$, with burnt cane and without the presence straw.

The application of the treatments was done using a backpack sprayer with a constant pressure of $\mathrm{CO}_{2}$ at $36 \mathrm{lb}$ inch $^{-2}$, furnished with spray bar with three flat nozzles was (Teejet Model DG 11002 VK, Wheaton, IL, USA). We used a spray application volume of $200 \mathrm{~L}^{\text {ha }}{ }^{1,}$ and the spacing between spray nozzles was $0.50 \mathrm{~m}$. Applications were held on November 20, 2013, with air temperature of $27.6{ }^{\circ} \mathrm{C}$ and $39.5^{\circ} \mathrm{C}$, winds ranging from 5 to $8 \mathrm{~km} \mathrm{~h}^{-1}$ and relative humidity between 62 and $54 \%$.

ETR was monitored at 1, 7, 14, 30, 49, 65 and 132 DAA, as described above. The measurement of ETR was made in the middle part of the TVD leaf, being six readings per plot, always in the morning, between 8 and 11 hours.

The determination of the number of stems and productivity was performed at 325 DAA two linear meters of each plot, manually harvested and separated (removal of the hands and dried leaves) and marked with the aid of a measuring tape. The productivity estimate $\left(\mathrm{Mg} \mathrm{ha}^{-1}\right)$ was performed by obtaining the mass of stems, with the help of scale (model 2098, Toledo, São Bernardo do Campo, SP, Brazil) coupled to a tractor.

Of these two meters, we removed 20 stalks randomly, which were sent to the technological analysis laboratory (Association of Cane Sugar Piracicaba Providers - AFOCAPI) for determination of soluble solids, percent broth weight (Brix) pol of sugarcane (pOL), and total recovered sugar content (ATR), according to methods proposed by Fernandes (2003).

The results were submitted to analysis of variance by $F$ test $(p>0.05)$, and the averages compared by $t$ test at $10 \%$ probability. The values of ETR were expressed as percentage of the average value of ETR control without herbicide application, being established confidence intervals (CI) data for the test at $10 \%$ probability. To determine the confidence interval, we used the following expression:

$$
C I=\frac{(\text { t. stdev })}{\sqrt{\mathrm{nr}}}
$$

where: $C I=$ confidence interval; $\mathrm{t}=\mathrm{t}$ value tabulated in the $10 \%$ level of probability; stdev = standard deviation; and $\mathrm{nr}=$ square root of the number of replications. 


\section{RESULTS AND DISCUSSION}

\section{Greenhouse experiments}

As the ETR parameter determines the electron transport rate in PSII, as described by Skorska and Swarcewicz (2005), the evaluation of the ETR to detect the effect of herbicide action at the level of concentration of 0.5 micromoles $\mathrm{dm}^{-3}$, while the traditional method, that includes measuring the Fv/Fm parameter, can detect only a concentration level which is 100 times higher (van Oorschot and van Leeuwen, 1992; Korres et al. 2003; Abbaspor et al., 2006) .

An intense and rapid effect was noted on reducing ETR compared to the control for amicarbazone at all tested doses and cultivars. The two higher doses caused the largest reductions of ETR of plants to 4 DAA and there was a gradual recovery in later periods (between 4:07 DAA). In CTC CTC 4 cultivars and 17 recoveries occurred more slowly than the others, and the differences between the doses were greater intensity in cultivating RB867515 (Figure 2).

The use of amicarbazone in the culture of sugarcane can present high selectivity so that more cultivars tolerant to this molecule have a lower absorption of the herbicide when compared to sensitive cultivars, which absorb more of it (Araldi et al., 2011).

Different doses tebuthiuron reduced ETR the four cultivars from 1 to 4 DAA, but these
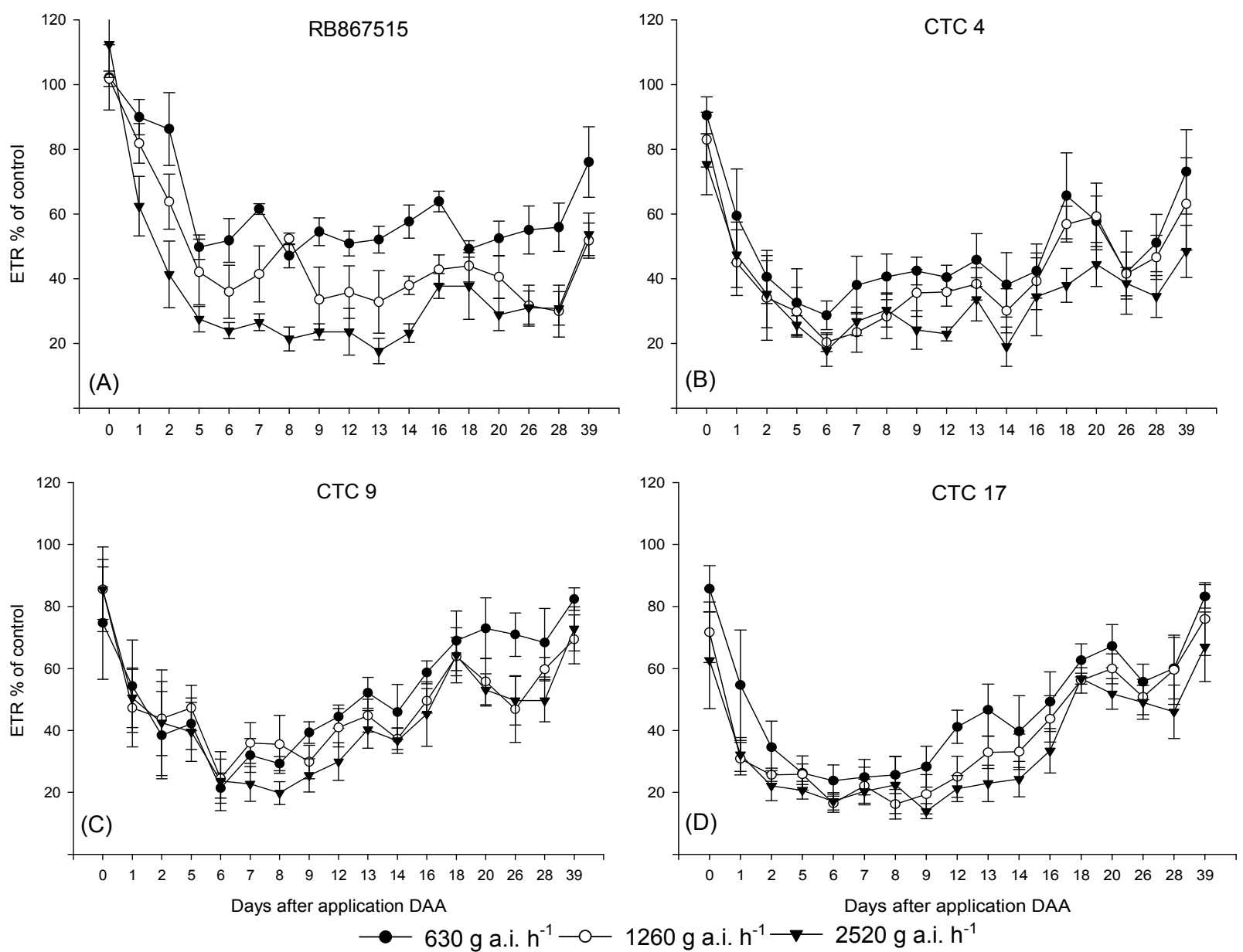

The bars indicate the CI of periods.

Figure 2 - Electron transport rate (\% of control) for sugarcane RB867515 (A), CTC 4 (B) CTC 9 (C) and CTC17 (D) after application of different doses of herbicide amicarbazone in a greenhouse. 

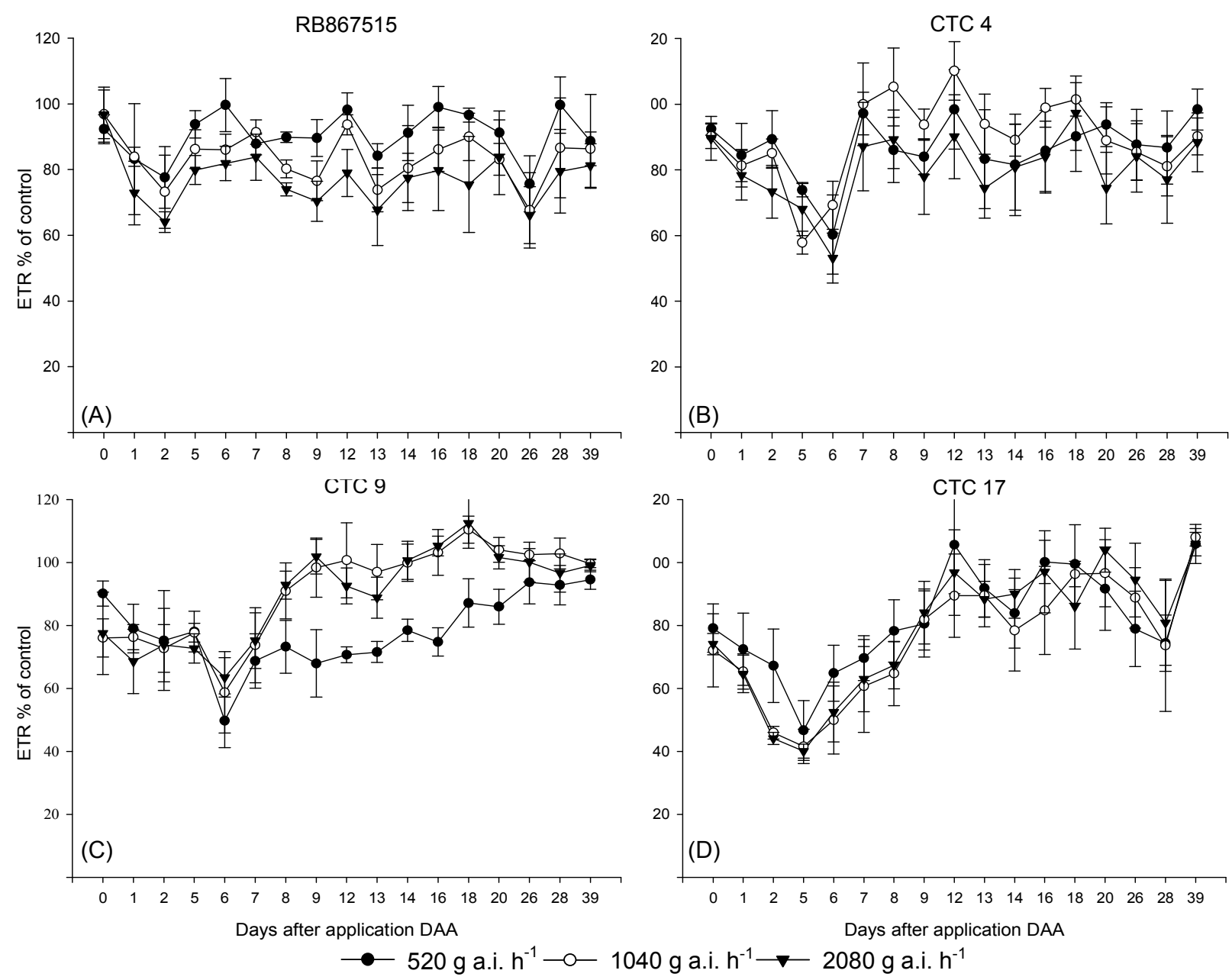

The bars indicate the CI of periods.

Figure 3 - Electron transport rate (\% of control) for sugarcane RB867515 (A), CTC 4 (B), CTC 9 (C), and CTC17 (D) after application of different doses of the herbicide tebuthiuron in a greenhouse.

reductions in ETR were less severe compared with those of other herbicides. After 5 DAA no changes were observed in relation to the control without the application of tebuthiuron in CTC 4, CTC 9 e CTC 17. For cultivar RB867515, reductions of ETR were less significant, especially in the early days after herbicide application (Figure 3) .

For hexazinone + diuron herbicide, it was observed that ETR between 1 and 4 DAA reached levels close to zero at all doses tested and cultivars. After 5 DAA started the recovery of plants, the effect of the different doses used was more evident, with recovery proportional to the doses in CTC 4, CTC 9 e CTC 17. To cultivar RB867515, the recoveries were observed mainly for the dose of $2,340+$ $660 \mathrm{~g}$ a.i. ha ${ }^{-1}$. This herbicide behavior diuron + hexazinone due to the fact that the two active ingredients used in this treatment is the PS II inhibitors which act at different sites on the quinone $b(\mathrm{Qb})$ and thus do not compete for sites available and enhance their phytotoxic effects to culture (Oliveira Jr. et al., 2011) (Figure 4).

As for the cultivars used in this study, when only observed ETR, it was found that the herbicide tebuthiuron resulted in a lower loss of ETR, followed by amicarbazone, with intermediate characteristics; hexazinone + diuron herbicide was the most affected ETR. 

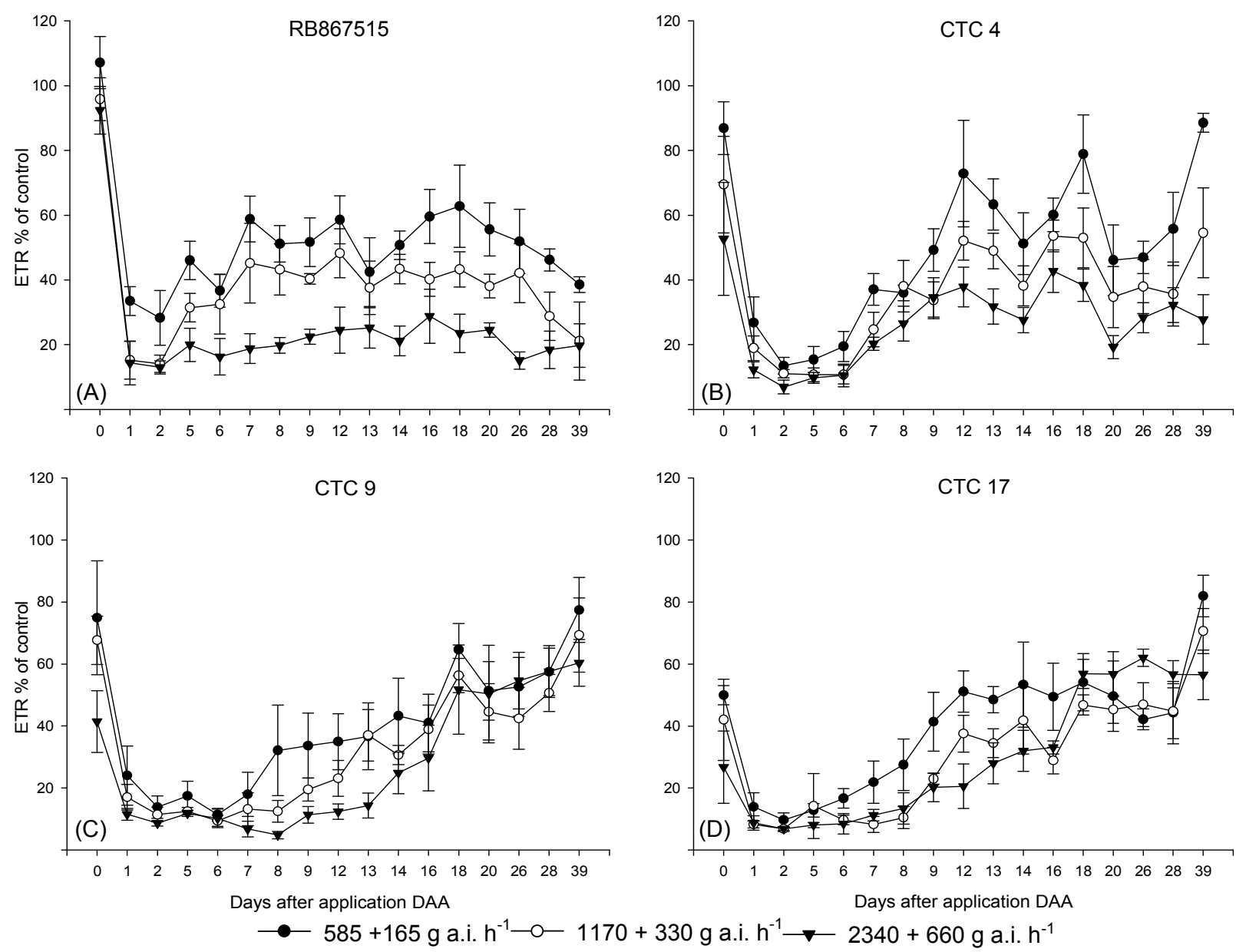

The bars indicate the CI of periods.

Figure 4 - Electron transport rate (\% of control) for sugarcane RB867515 (A), CTC 4 (B), CTC 9 (C), and CTC17 (D) after application of different doses of the herbicide diuron + hexazinone in a greenhouse.

The amicarbazone and herbicides diuron + hexazinone showed phytotoxicity proportional to the dose used in the four cultivars. For the herbicide tebuthiuron, there was no phytotoxicity in cultivars CTC 4, CTC 9, and CTC 17; to cultivar RB867515 it was only observed at the highest dose. These results are related to the sharp fall in the ETR in the first days after application, particularly in herbicides diuron + hexazinone and amicarbazone (Figure 5). Souza et al. (2009) found that different cultivars of sugarcane submitted to herbicides amicarbazone and diuron + hexazinone under field conditions showed 10 poisonings and $12 \%$, respectively, at 15 DAA. Smith et al. (2011), working with experiments in pots with cultivars
IAC91-5155, IACSP93-3046 and IACSP942094, found that amicarbazone herbicide $\left(1,400 \mathrm{~g}\right.$ a.i. $\left.\mathrm{ha}^{-1}\right)$ at $13 \mathrm{DAA}$, caused $40 \%$ phytotoxicity at all tested cultivars. In this study, the percentage of phytotoxicity to 35 DAA amicarbazone at a dose of $1,260 \mathrm{~g}$ a.i. ha ${ }^{-1}$ was $25,27,20$ and $28 \%$ to the RB867515 cultivars CTC 4, CTC 9 and CTC 17, respectively.

With regard to mass data shoot dry matter, we observed a similar behavior of herbicides amicarbazone and hexazinone + diuron, with the largest decreases in the higher dose. For tebuthiuron, mass reductions were lower in cultivating RB867515, and only at the rate of 2,080 g a.i. ha-1 was observed reduction of biomass. In cultivating CTC 17 tebuthiuron 

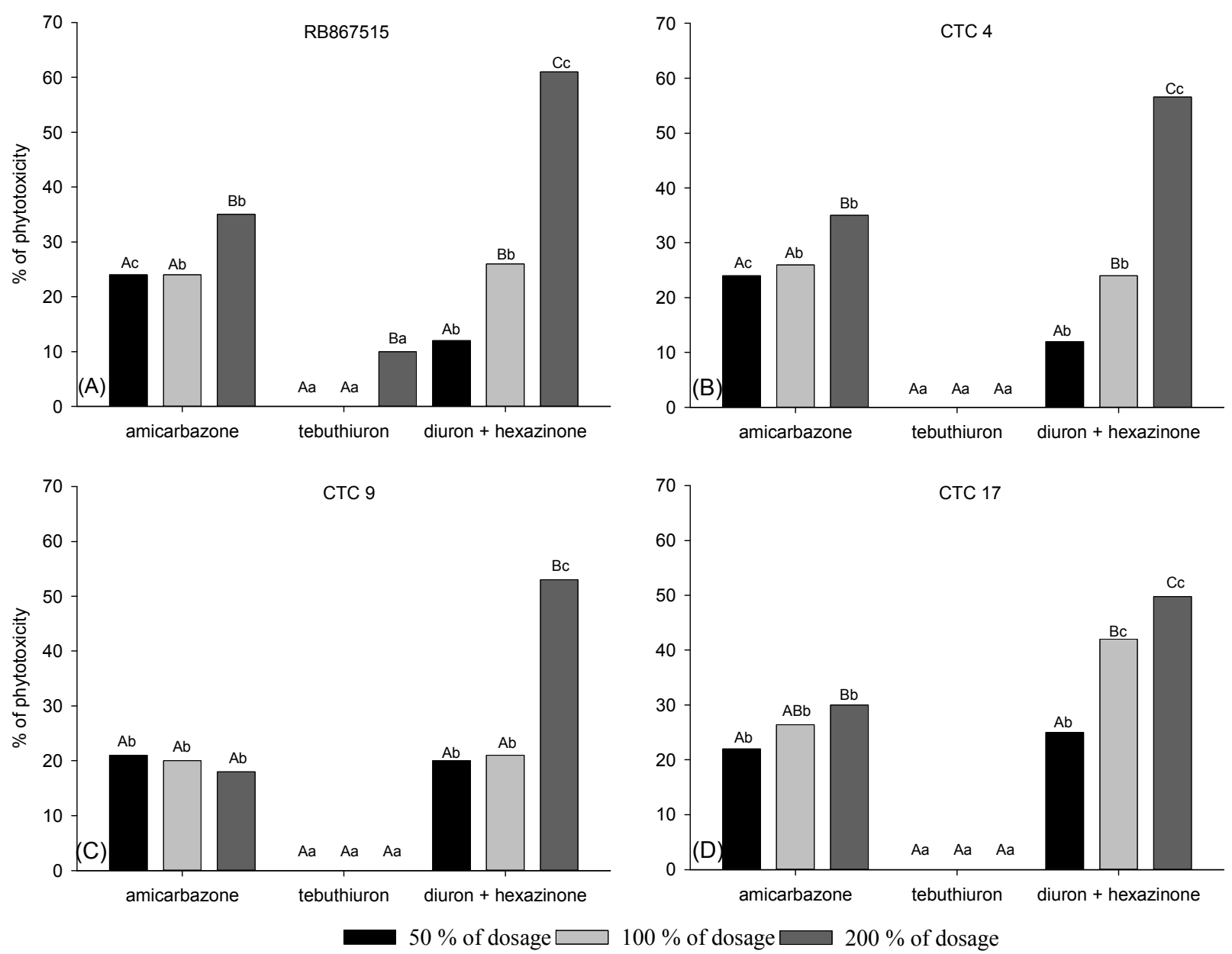

Amicarbazone $\left(50 \%=630 \mathrm{~g}\right.$ a.i. $\mathrm{ha}^{-1} ; 100 \%=1,260 \mathrm{~g}$ a.i. $\mathrm{ha}^{-1} ; 200 \%=2,520 \mathrm{~g}$ a.i. ha $\left.{ }^{1}\right)$, tebuthiuron $\left(50 \% 520 \mathrm{~g}\right.$ a.i. ha ${ }^{1} ; 100 \%=1,040 \mathrm{~g}$; $200 \%=2,080 \mathrm{~g}$ a.i. ha $\left.{ }^{-1}\right)$ and diuron + hexazinone $\left(50 \%=585+165 \mathrm{~g}\right.$ a.i. ha ${ }^{-1} ; 100 \%=1,170+330 \mathrm{~g}^{2} . \mathrm{i} . \mathrm{ha}^{-1} ; 200 \%=2,340+$ 660 g a.i. ha ${ }^{1}$ ).

Lowercase letters differ from equal doses of different herbicides and different capital letters differ from the same herbicide doses.

Figure 5 - Phytotoxicity to sugarcane RB867515 (A), CTC 4(B), CTC 9 (C), and CTC17 (D) at 35 days after application of treatments in the greenhouse.

all doses reduced the dry mass, but with lower intensity compared to the other tested herbicides.

Ferreira et al. (2010) studied the application of tebuthiuron $(1,200 \mathrm{~g}$ a.i. ha-1) and diuron + hexazinone $\left(1,170+330 \mathrm{~g}\right.$ a.i. ha $\left.{ }^{-1}\right)$ in cultivating sugarcane CTC 4 and observed mass of dry matter accumulation, in relation to the control of 95.05 and $47.7 \%$, respectively.

\section{Field experiments}

We have found that ETR was reduced on the first day after the application in all treatments and cultivars, with a greater reduction caused by hexazinone + diuron (Figure 7). Complete recovery was observed ETR levels of from 14 DAA, which were similar to those plants which received no herbicide application. This demonstrates initial and transient effect of herbicides on ETR the four cultivars. Azania et al. (2006) observed that the mixture diuron + hexazinone caused a significant decrease in fluorescence ratio $(\mathrm{Fv} / \mathrm{Fm})$ at 45 and 60 DAA in application in early post-emergence of the plants of sugarcane in times with high rainfall and drought. 
Regarding the number of stems, there was an increase in farming RB867515 for application of tebuthiuron and diuron + hexazinone (Figure 8). As for the other cultivars, no differences were observed between treatments. Negrisoli et al. (2004) found no reduction in the number of culms studying the selectivity of tebuthiuron applied pre-emergence and nematicides associated with the culture of sugarcane.

For the four cultivars, it was observed that the treatments did not affect productivity. To cultivate RB867515, it was observed that the herbicide tebuthiuron and diuron + hexazinone promoted increases in productivity compared to the control, as occurred in the number of stems. It can be inferred that this productivity increase is related to higher number of stems that were presented by plants treated with these herbicides, as noted above. Similar results were described by Azania et al. (2005) for reviews of culms and productivity in farming RB835089 submitted to the application of metribuzin and isoxaflutole.

A total of $14.31 \%$ productivity increase was obtained by Schiavetto (2012) in cultivating SP81-3250 treated with metsulfuronmethyl herbicide $\left(6 \mathrm{~g} \mathrm{ha}^{-1}\right)+$ sulfentrazone $\left(750 \mathrm{~g} \mathrm{ha}^{-1}\right)$ and ametryn $\left(1,097.25 \mathrm{~g} \mathrm{ha}^{-1}\right)+$
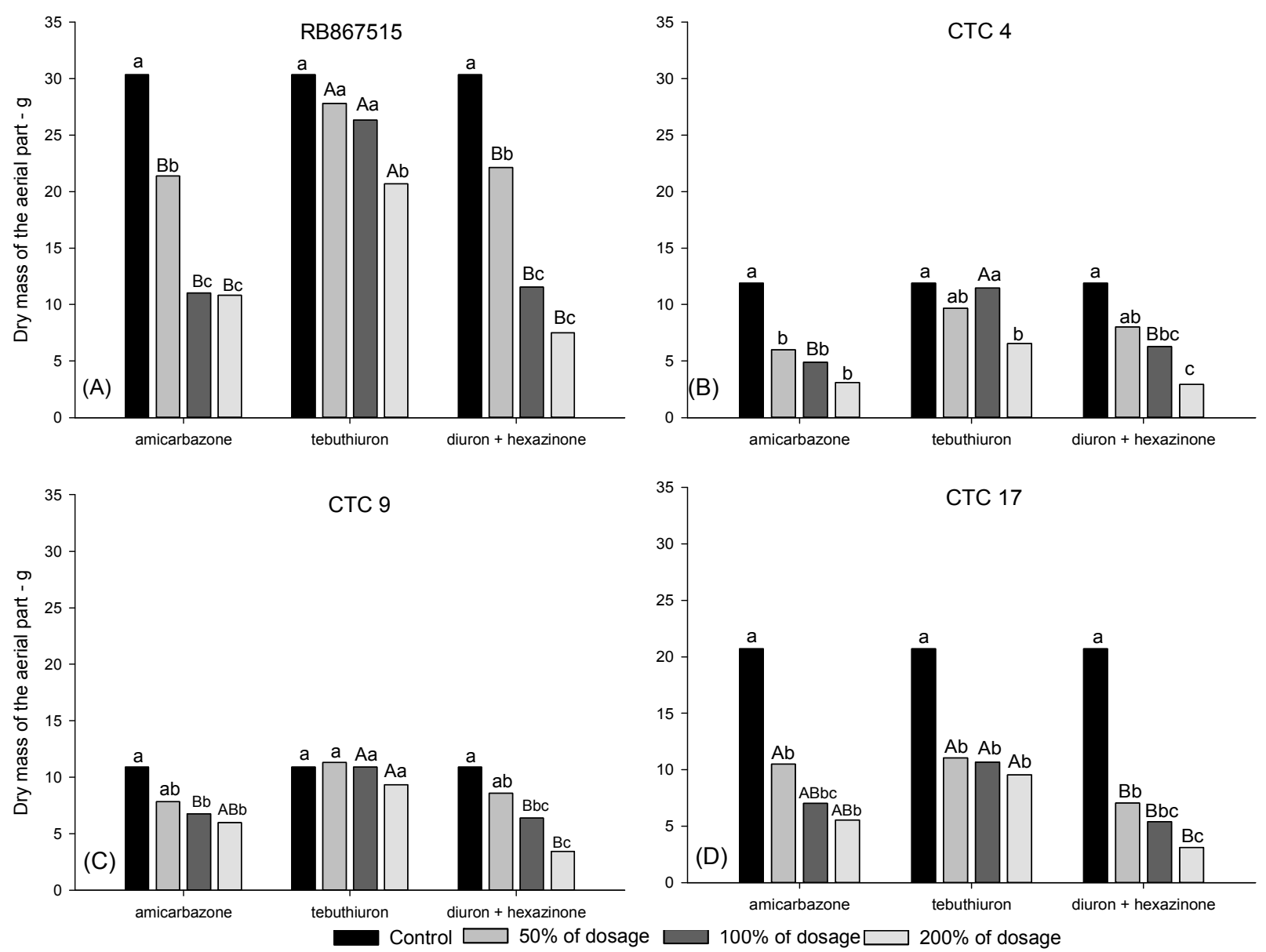

Amicarbazone $\left(50 \%=630 \mathrm{~g}\right.$ a.i. $\mathrm{ha}^{-1} ; 100 \%=1,260 \mathrm{~g}$ a.i. $\mathrm{ha}^{-1} ; 200 \%=2,520 \mathrm{~g}$ a.i. ha $\left.{ }^{-1}\right)$, tebuthiuron $\left(50 \%=520 \mathrm{~g}\right.$ a.i. ha ${ }^{-1} ; 100 \%=1,040 \mathrm{~g}$; $200 \%=2,080 \mathrm{~g}$ a.i. ha $\left.{ }^{-1}\right)$ and diuron + hexazinone $\left(50 \%=585+165 \mathrm{~g}\right.$ a.i. ha ${ }^{-1} ; 100 \%=1,170+330 \mathrm{~g} \mathrm{a} . \mathrm{i} . \mathrm{ha}^{-1} ; 200 \%=2,340+660 \mathrm{~g}$ a.i. ha-1) Uppercase differ from equal doses of different herbicides and different small letters differ from the same herbicide doses.

Figure 6 - Mass of dry shoots for sugarcane RB867515 (A), CTC 4(B), CTC 9 (C), and CTC17 (D) at 35 days after application of treatments in greenhouse. 

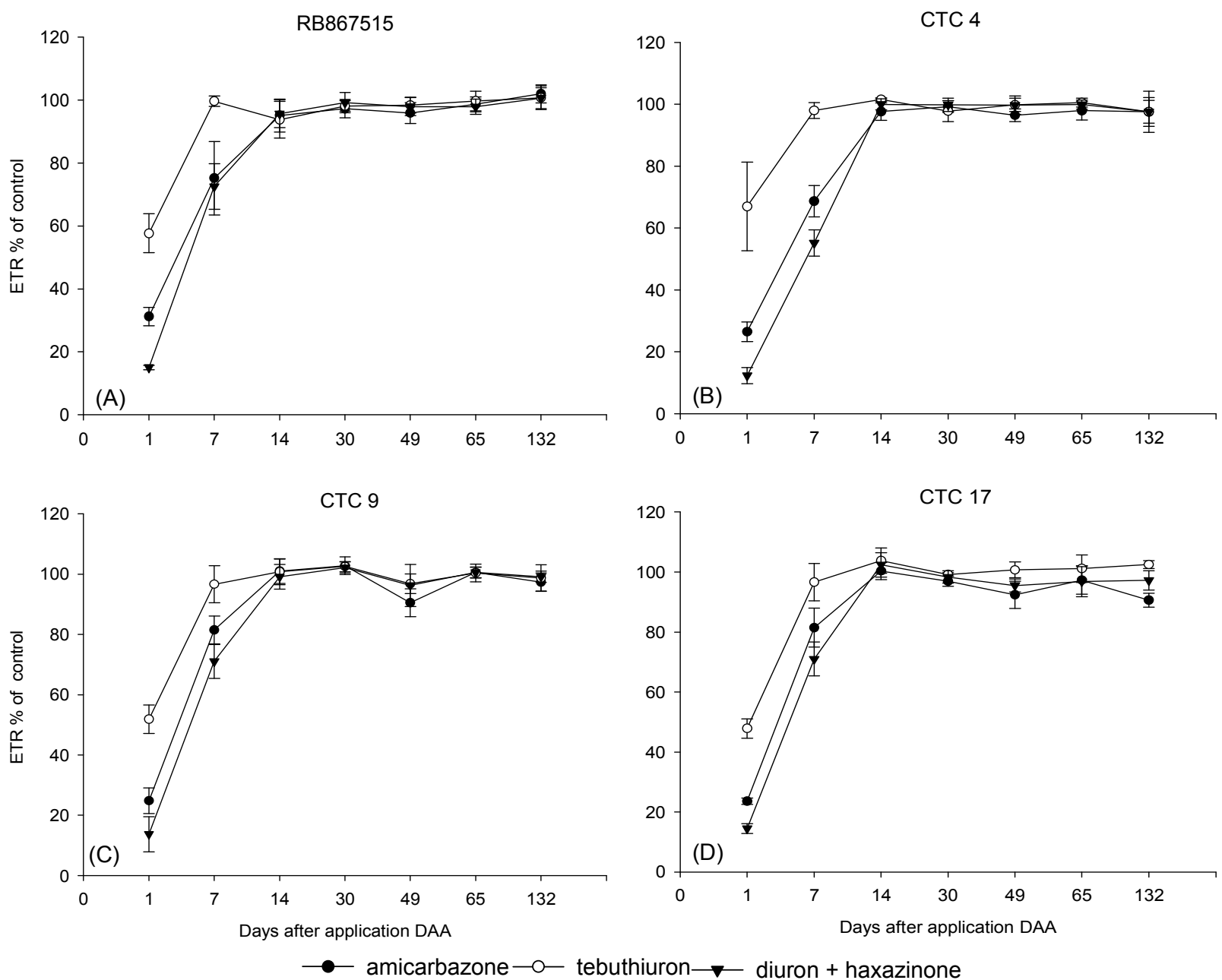

The bars indicate the IC of periods.

Figure 7 - Electron transport rate (\% of control) for sugarcane in RB867515 cultivars (A), CTC 4 (B), CTC 9 (C), and CTC17 (D), after application of Amicarbazone herbicides $\left(1,260 \mathrm{~g}\right.$ a.i. ha $\left.\mathrm{h}^{-1}\right)$, tebuthiuron $\left(1,040 \mathrm{~g}\right.$ a.i. $\left.\mathrm{ha}^{-1}\right)$ and diuron + hexazinone $(1,170+$ $330 \mathrm{~g}$ a.i. $\mathrm{ha}^{-1}$ ) in the field.

trifloxysulfuron-sodium $\left(27.75 \mathrm{~g} \mathrm{ha}^{-1}\right)+$ diuron (702 $\left.\mathrm{g} \mathrm{ha}^{-1}\right)+$ hexazinone (198 $\mathrm{g} \mathrm{ha}^{-1}$ ) compared to untreated plants. According to this author, this effect may be due to the inherent characteristic of genetic cultivar and also the increase stems.

When evaluated the technological parameters BRIX, POL and ATR, there was no significant difference between the treatments used and cultivars (Table 2). Similar results were found by Souza et al. (2009), when evaluating the technological characteristics of different cultivars of sugarcane submitted to amicarbazone herbicide tebuthiuron and diuron + hexazinone and concluded that both productivity and technological quality were not affected by herbicides.

Based on the present results, it can be concluded that: in subsidiaries of greenhouse conditions tebuthiuron caused the lowest levels of reduction of ETR, phytotoxicity and dry matter of different cultivars of sugarcane compared to amicarbazone and diuron + hexazinone; the effects of herbicides on ETR and phytotoxicity were much more intense in the greenhouse than in the field for the different cultivars; in the field, tebuthiuron herbicides, amicarbazone and diuron + hexazinone were selective for the different cultivars and caused no negative effects on 

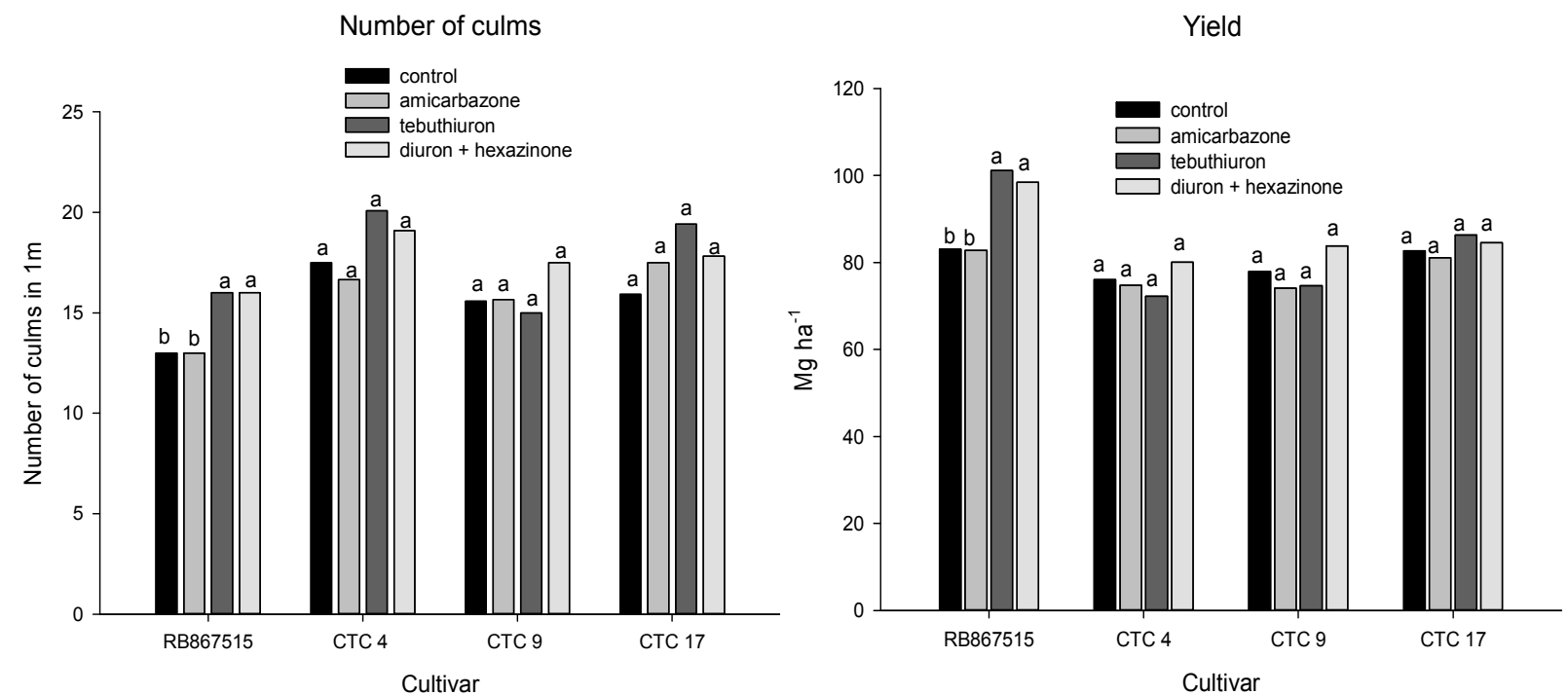

Amicarbazone $\left(1,260 \mathrm{~g}\right.$ a.i. ha $\left.{ }^{-1}\right)$ tebuthiuron $\left(1,040 \mathrm{~g}\right.$ a.i. ha $\left.{ }^{-1}\right)$ and diuron + hexazinone $\left(1,170+330 \mathrm{~g}\right.$ a.i. ha $\left.{ }^{-1}\right)$.

Bars with different letters differ within each cultivar.

Figure 8 - Number of culms in 1 estimated yield me in $\mathrm{mg} \mathrm{ha}^{-1}$ to 325 days after the application in RB867515 cultivars CTC 4, 9 and CTC CTC 17 submitted to different treatments.

Table 2 - Technological features of RB 867515 variety, CTC 4, 9 and CTC CTC 17 to 325 DAA

\begin{tabular}{|c|c|c|c|c|c|c|}
\hline \multirow{2}{*}{ Treatment } & \multicolumn{3}{|c|}{ RB 867515} & \multicolumn{3}{|c|}{ CTC 4} \\
\hline & Brix & Pol & ATR & Brix & Pol & ATR \\
\hline Control & 23.5 & 17.5 & 172.15 & 23.46 & 17.11 & 168.65 \\
\hline Amicarbazone & 23.5 & 17.4 & 171.68 & 23.53 & 17.27 & 170.06 \\
\hline Tebuthiuron & 23.6 & 17.6 & 172.92 & 23.35 & 16.97 & 167.26 \\
\hline Diuron + hexazinone & 23.1 & 17.2 & 170.38 & 23.57 & 17.26 & 170.07 \\
\hline$F$ trat & $0.622^{\mathrm{ns}}$ & $0.250^{\mathrm{ns}}$ & $0.199^{\mathrm{ns}}$ & $1.346^{\mathrm{ns}}$ & $1.217^{\mathrm{ns}}$ & $1.307^{\mathrm{ns}}$ \\
\hline F block & $0.258^{\mathrm{ns}}$ & $0.490^{\mathrm{ns}}$ & $0.442^{\mathrm{ns}}$ & $3.537 *$ & $2.207^{\mathrm{ns}}$ & $2.191^{\mathrm{ns}}$ \\
\hline VC $(\%)$ & 2.69 & 3.54 & 3.41 & 0.87 & 1.82 & 1.7 \\
\hline LSD & 0.63 & 0.62 & 5.95 & 0.2 & 0.31 & 2.9 \\
\hline \multirow{2}{*}{ Treatment } & \multicolumn{3}{|c|}{ CTC 9} & \multicolumn{3}{|c|}{ CTC 17} \\
\hline & Brix & Pol & ATR & Brix & Pol & ATR \\
\hline Control & 23.36 & 17.39 & 168.17 & 22.69 & 17.07 & 168.27 \\
\hline Amicarbazone & 23.15 & 17.30 & 170.29 & 22.95 & 17.29 & 170.26 \\
\hline Tebuthiuron & 23.39 & 17.57 & 172.56 & 22.83 & 17.34 & 170.73 \\
\hline Diuron + hexazinone & 23.32 & 17.72 & 174.19 & 22.94 & 17.16 & 168.93 \\
\hline$F$ trat & $0.194^{\mathrm{ns}}$ & $0.731^{\mathrm{ns}}$ & $1.223^{\mathrm{ns}}$ & $0.240^{\mathrm{ns}}$ & $0.438^{\mathrm{ns}}$ & $0.447^{\mathrm{ns}}$ \\
\hline F block & $0.777^{\mathrm{ns}}$ & $0.822^{\mathrm{ns}}$ & $1.144^{\mathrm{ns}}$ & $0.831^{\mathrm{ns}}$ & $0.607^{\mathrm{ns}}$ & $0.587^{\mathrm{ns}}$ \\
\hline $\mathrm{VC}(\%)$ & 2.58 & 3.02 & 3.4 & 3.67 & 2.62 & 2.47 \\
\hline LSD & 0.6 & 0.53 & 5.9 & 0.61 & 0.45 & 4.24 \\
\hline
\end{tabular}

Brix $=\%$ soluble solids broth; Pc $=$ pol cane; ATR (ATR kg TC ${ }^{-1)}$ Total sugar significant recovered $* 5 \%$ and $* * 1 \%$ probability; ns $=$ not significant by $\mathrm{F}$ test; Means followed by different letters in the column differ by $10 \%$ ta test. 
productivity and quality of sugarcane; 角nd even with the reductions ETR after herbicide application no influence on the development of the sugarcane crop.

\section{REFERENCES}

Abbaspoor M., Teicher H.B., Streibig J.C. The effect of rootabsorbed PSII inhibitors on Kautsky curve parameters in sugar beet. Weed Res. 2006;46:226-35.

Anderson W.P. Weed science principles. New York: West Publlication, 1993. 655p.

Araldi R. et al. Avaliação da intoxicação de cultivares de canade-açúcar e I. grandifolia ao amicarbazone. Planta Daninha. 2011;29:869-75.

Azania C.A.M. et al. Seletividade de herbicidas. I-Utilização do método de testemunhas pareadas em experimento com cana-de-açúcar. Planta Daninha. 2005;23:661-7.

Azania C.A.M. et al. Seletividade de herbicidas. III Aplicação de herbicidas em pós-emergência inicial e tardia da cana-de-açúcar na época da estiagem. Planta Daninha. 2006;24:489-95.

Companhia Nacional de Abastecimento - Conab. Acompanhamento da safra brasileira de cana. v.3 - Safra 2016/17. Primeiro levantamento. Brasília: 2016. p.1-66.

Empresa Brasileira de Pesquisa Agropecuária - Embrapa. Centro Nacional de Pesquisa de Solos. Manual de métodos de análise de solo. $2^{\mathrm{a}}$. ed. Rio de Janeiro: 1997. 212p.

Fernandes A.C. Cálculos na Agroindústria da cana-deaçúcar. $2^{\mathrm{a}}$. ed. Piracicaba: STAB, 2003. 240p.

Ferreira R.R. et al. Tolerância diferencial de cultivares de canade-açúcar a estresse por herbicidas. Bragantia. 2010;69:395404.

Franconere R. Mercado de herbicidas na cultura da canade-açúcar [dissertação]. São Paulo: Escola de Economia de São Paulo, Fundação Getúlio Vargas, 2010. 54p.

Korres N.E., Froud-Williams R.J., Moss S.R. Chlorophyll fluorescence technique as a rapid diagnostic test of the effects of the photosynthetic inhibitor chlortoluron on two winter wheat cultivars. Ann Appl Biol. 2003;143:53-6.
Negrisoli E. et al. Seletividade de herbicidas aplicados em pré-emergência na cultura de cana-de-açúcar tratada com nematicidas. Planta Daninha. 2004;22:567-75.

Oliveira Jr R.S., Inoue M.H. Seletividade de herbicidas para culturas e plantas daninhas. In: Oliveira Jr R.S., Constantin J.E Inoue M.H. Biologia e manejo de plantas daninhas. $22^{\mathrm{a}}$. ed. Curitiba: Omnipax, 2011. p.243-61.

Oliveira Jr R.S., Constantin J. Plantas daninhas e seu manejo. Guaíba: Agropecuária, 2001. 362p.

Raij B van et al. Recomendações de adubação e calagem para o estado de São Paulo. Campinas: Instituto Agronômico/Fundação IAC, 1997. 285p. (Boletim técnico 100)

Raij B van et al. Análise química para avaliação da fertilidade de solos tropicais. Campinas: Instituto Agronômico, 2001. 285p.

Rodrigues B.N., Almeida F.S. Guia de herbicidas. $6^{\mathrm{a}}$. ed. Londrina: Grafmarke, 2011.697p.

Schiavetto A.R. et al. Tolerância de cana-de-açúcar a herbicidas avaliada pela diferença dos tratamentos. Planta Daninha. 2012;30:173-84.

Skórska E., Swarcewicz M. Comparison of some adjuvants efficacy with azoprim and buramet using chlorophyll fluorescence. Comm Agric Appl Biol Sci. 2005;71:141-6.

Soares R.O. et al. Herbicidas de diferentes mecanismos de ação e a seletividade a cultivares de cana-de-açúcar. Nucleus. 2011;8:1-14.

Sociedade Brasileira de Ciência das Plantas Daninhas SBCPD. Procedimentos para instalação, avaliação e análise de experimentos com herbicidas. Londrina: 1995.

Souza J.R. et al. Tolerância de cultivares de cana-de-açúcar a herbicidas aplicados em pós-emergência. Bragantia. 2009;68:941-51.

van Oorschot J.L.P., van Leeuwen P.H. Use of fluorescence induction to diagnose resistance of Alopecurus myosuroides Huds. (black-grass) to chlortoluron Weed Res. 1992;32:47382. 